\title{
Slawomir Bartnicki*
}

Uniwersytet w Białymstoku

\section{Janina Kowalik**}

Uniwersytet Jana Kochanowskiego w Kielcach

\section{WYBORCZA KARUZELA: STAŻ PARLAMENTARNY JAKO CZYNNIK SUKCESU WYBORCZEGO KANDYDATÓW NA WÓJTA, BURMISTRZA I PREZYDENTA MIASTA ${ }^{1}$}

\begin{abstract}
Przedmiotem artykułu jest analiza wpływu stażu parlamentarnego kandydatów ubiegających się w wyborach bezpośrednich o stanowiska wójtów, burmistrzów i prezydentów miast na odsetek uzyskiwanych przez nich głosów. Wśród ogółu zakwalifikowanych startów wyborczych od 2002 do 2014 roku do stanowisk kierowników gminnej egzekutywy $(N=33680)$, w 327 przypadkach o to stanowisko ubiegały się osoby ze stażem parlamentarnym, czyli zasiadający w Parlamencie RP uprzednio (od 2001 roku) i/lub w trakcie poszczególnych bezpośrednich wyborów wójtów, burmistrzów, prezydentów miasta. Wyniki analizy wskazują na to, że staż parlamentarny odbiera głosy w gminach o mniejszej liczbie mieszkańców, nie jest natomiast efektywną zmienną wpływającą na wzrost szansy wyboru w dużych ośrodkach miejskich.
\end{abstract}

Słowa kluczowe: wójt, burmistrz, prezydent miasta, czynniki reelekcji, parlamentarzyści w samorządzie

\section{WPROWADZENIE}

Wybory kierowników gminnej egzekutywy organizowane od 2002 roku w trybie wyborów bezpośrednich dają możliwości precyzyjnego ustalenia uwarunkowań stopnia poparcia kandydatów na te stanowiska. Czynników takich poszukuje się zarówno wśród cech samych kandydujących, jak i wśród cech okręgów wyborczych (gmin), które rzutują na zachowania elektoratu. Te dwie grupy czynników wyjaśniają pełne spektrum szans wyborczych, na

* Adres do korespondencji: Sławomir Bartnicki, Instytut Socjologii i Kognitywistyki Uniwersytetu w Białymstoku, plac Uniwersytecki 1, 15-420 Białystok; e-mail: s.bartnicki@uwb.edu.pl.

** Adres do korespondencji: Janina Kowalik, Instytut Polityki Międzynarodowej i Bezpieczeństwa Uniwersytetu Jana Kochanowskiego w Kielcach, ul. Świętokrzyska 21, 25-406 Kielce, e-mail: janinakowalik@op.pl.

1 Artykuł jest efektem grantu finansowanego przez Narodowe Centrum Nauki (2014/13/D/HS5/02010), pt. „Uwarunkowania reelekcji egzekutywy gminnej po 2002 roku w Polsce". 
jakie może liczyć kandydujący w tego typu wyborach. W niniejszym artykule empirycznej weryfikacji zostanie poddany jeden $\mathrm{z}$ takich czynników, wpisujących się w zakres cech opisujących kandydata - doświadczenie parlamentarne ubiegających się o stanowiska wójtów, burmistrzów i prezydentów miast.

W dalszej części artykułu przedstawiono czynniki budujące rozmiar poparcia wyborczego kandydujących w tego typu wyborach, ze szczególnym uwzględnieniem wpływu, jaki wywiera status osoby ponownie ubiegającej się o mandat (inkumbenta). Następnie scharakteryzowano dane używane w tej analizie, metody badawcze oraz przyjmowane założenia, dla których podstawą są dotychczasowe wnioski płynące z badań empirycznych i literatury przedmiotu. Artykuł kończy się analizą danych, w której zweryfikowano sugerowane przewidywania, oraz wnioskami końcowymi.

\section{CZYNNIKI SUKCESU WYBORCZEGO W WYBORACH WÓJTÓW, BURMISTRZÓW I PREZYDENTÓW MIAST}

Na całym świecie, w różnych typach wyborów demokratycznych wygrywają najczęściej zajmujący dane stanowisko w kadencji poprzedniej, tzw. inkumbenci. Zjawisko to określa się jako incumbency advantage i oznacza ono rentę z tytułu sprawowania funkcji podlegającej wyborom bezpośrednio przed daną elekcją. Dowody na istnienie incumbency advantage płyną z różnych stron świata i dotyczą wyborów na stanowiska lokalnej władzy wykonawczej i uchwałodawczej w USA (Trounstine 2011; Krebs 1998); lokalnej egzekutywy w Niemczech (Freier 2015); w Słowenii (Kuković i Hacek 2013), jak i wyborów parlamentarnych w USA(Gelman i King 1990; Lee 2001 i 2008; Stonecash 2008); w Niemczech (Heinmueller i Kern 2008) czy na przykład we Francji (Lemennicier i Katir-Lescieux 2010). Z odwrotnym zjawiskiem obciążenia faktem wcześniejszego sprawowania urzędu dla ubiegających się o reelekcję (tzw. incumbency disadvantage), mamy do czynienia incydentalnie, przykładowo takie zdarzenia w zakresie wyborów lokalnej egzekutywy odnotowano w Brazylii (Titiunik 2011) czy też w Indiach w przypadku wyborów centralnych (Uppal 2009; Duraisamy, Lemennicier i Khouri 2014). Przyczyną takiego stanu rzeczy może być silna delegitymizacja władzy o podłożu ekonomicznym (Macdonald 2014: 3).

Status inkumbenta jest czynnikiem najsilniej wpływającym na sukces wyborczy (Oliver, Ha i Callen 2012). Źródeł przewagi osób ponownie ubiegających się o wybór upatrujemy w czynnikach strukturalnych i pozastrukturalnych. Te pierwsze wynikają z zasobów, jakimi dysponują sprawujący władzę. Możemy tu wymienić na przykład częstą ekspozycję w mediach, spotkania $\mathrm{z}$ wyborcami $\mathrm{w}$ ramach pełnionej funkcji, ale też rozbudowane możliwości autopromocji, które w charakteryzowanym typie wyborów mogą się urzeczywistniać na przykład za pomocą biuletynów informacyjnych gmin, w gminach o relatywnie niewielkiej liczbie ludności.

Do pozastrukturalnych czynników przewagi kandydatów ubiegających się o reelekcję zaliczamy działania, które są pochodną przewag strukturalnych. Po pierwsze, rządzący mogą zwiększać prawdopodobieństwo przyszłej reelekcji przez manipulowanie budżetem (Kowalik 2006: 194), a po drugie, przez inwestowanie w relacje klientelistyczne. Manipulowanie 
Wyborcza karuzela: staż parlamentarny jako czynnik sukcesu wyborczego kandydatów na wójta...

budżetem oznacza zwiększanie wydatków i długu publicznego oraz zmniejszanie obciążeń fiskalnych w okresie przedwyborczym (Drazen 2008), kiedy to wyborcy mają być szczególnie podatni na takie działania (Sarpietro 2014: 4-5). Podatność wyborców na uroki politycznego cyklu budżetowego (Political Business Cycle) nie musi występować (Peltzman 1992), co jest charakterystyczne raczej dla dojrzałych demokracji (Brender i Drazen 2008). Zwykle jednak, na przykład w wyborach lokalnych, działania takie przynoszą zamierzone skutki (np. Veiga i Veiga 2007). Z kolei budowanie przez rządzących relacji klientelistycznych w praktyce może oznaczać, że w zależności od uwarunkowań sytuacyjnych raz występują oni w roli patronów (np. wobec wyborców, podległych pracowników, lokalnych przedsiębiorców), a raz w roli klientów (np. wobec lokalnych i ponadlokalnych przedsiębiorców czy lokowanych wyżej w hierarchii przedstawicieli aparatów partyjnych). Analitycznie tworzone relacje klientelistyczne mogą daleko odbiegać od klasycznych układów diady charakteryzowanych przez Jacka Tarkowskiego (Tarkowski 1994). Relacje te mogą tu przyjmować postać klientelizmu masowego, indywidualnego, kronizmu czy nawet parantelizmu (Własiuk 2011).

Jednoznaczne określenie, w jakim zakresie na sukces reelekcyjny urzędników wpływa wyłącznie ich staż na stanowisku, a w jakim czynniki, takie jak manipulowanie budżetem, relacje klientelistyczne czy na przykład umiejętna autopromocja, nie jest możliwe. Wszystkie te czynniki odgrywają tu rolę w sprzężeniu z uwarunkowaniami lokalnymi, takimi jak liczba ludności gminy, jej położenie, zasoby warunkujące stan budżetu gminy i inne cechy środowiska lokalnego i pozalokalnego (np. zadania zlecane gminom przez władze centralne).

Innymi, obok bezpośrednio wcześniejszego doświadczenia na stanowisku, cechami indywidualnymi, które mogą współokreślać siłę poparcia wyborczego są: płeć, wiek, wykształcenie, doświadczenie zawodowe kandydata (Taylor i McEleney 2015). W ten zakres cech kandydatów wpisywać można także czynnik, który interesuje nas szczególnie w tej analizie, czyli staż parlamentarny. Wpływ podobnego czynnika na odsetek zdobywanych głosów w przypadku wyborów do rady miejskiej Chicago analizował Timothy Krebs (Krebs 1998).

Do cech okręgów wyborczych, którymi w przypadku tych wyborów są gminy, zaliczymy czynniki mierzalne dotyczące różnych obszarów, jak na przykład: liczbę kandydatów, strukturę wydatków, dochodów, zakres uzbrojenia w infrastrukturę podstawową, nasycenie podmiotami gospodarczymi (publicznymi i niepublicznymi) z uwzględnieniem ich wielkości i branży, posiadanie na swoim terenie zasobów deficytowych czy położenie w danym regionie historycznym itp. Wymienione cechy mają związek z wielkością gminy, liczebnością mieszkańców czy odległością od najbliższego miasta wojewódzkiego.

\section{DANE}

W bieżącej analizie wykorzystywana jest jedna $\mathrm{z}$ baz danych zbudowana na potrzeby projektu „Uwarunkowania reelekcji egzekutywy gminnej po 2002 roku w Polsce”. Jednostkami obserwacji są tu zakwalifikowane starty wyborcze kandydatów we wszystkich dotychczasowych wyborach bezpośrednich do stanowisk wójtów, burmistrzów i prezydentów miast w 2428 gminach z terenu całego kraju. Z analizy wykluczono starty w tych gminach, w których w jakichkolwiek dotychczasowych wyborach bezpośrednich kierownik gminnej egzekutywy 
wyłaniany był przez radę gminy lub konieczne było przeprowadzenie III tury wyborów (w sumie 48 przypadków). Z analizy wykluczono także obydwie gminy Zielona Góra, ponieważ w 2014 roku w gminach tych nie odbywały się wybory ze względu na ich scalenie. Kolejna wyłączona z analizy gmina to Jaśliska ze względu na fakt, że na mapie administracyjnej kraju funkcjonuje ona dopiero od 2010 roku. Wyłączenia te mają związek z koniecznością zachowania jednolitości porównywanych danych we wszystkich cyklach wyborów bezpośrednich. Uwzględniając te wykluczenia, w sumie w 2428 gminach odnotowano 33680 startów wyborczych we wszystkich dotychczasowych wyborach bezpośrednich kierowników gminnej egzekutywy².

Baza danych odnotowuje cechy dla 33680 obserwacji (startów wyborczych w dotychczasowych wyborach bezpośrednich kierowników gminnej egzekutywy), w zakresie takich cech kandydujących, jak między innymi: wiek, płeć, afiliacja komitetu wyborczego, miejsce na liście wyborczej (zależne w tym przypadku od pierwszej litery nazwiska kandydata), wykształcenie, siła kandydata w wyborach $x$ (odsetek zdobywanych głosów w I turze) i wiele innych. W zakresie cech gmin baza odnotowuje dane zarówno według wartości bezwzględnych wybranych zmiennych w danym roku wyborów, jak i w zakresie wartości względnych i kompilowanych charakteryzujących różnorakie cechy gmin w różnych odcinkach czasowych. Taka macierz danych umożliwia wielowątkowe poszukiwania przyczyn sukcesów i porażek wyborczych kandydatów na podstawie teoretycznie i empirycznie istotnych zmiennych dotyczących osób i okręgów wyborczych. Otrzymujemy tu również w miarę rozległe pole do testowania wpływu wybranych zmiennych. Dane wykorzystywane w bieżącej analizie osadzone w charakteryzowanej bazie pozyskiwano z: PKW, GUS, Sejm.gov.pl, Senat.gov.pl, MamPrawoWiedziec.pl, Wikipedia.pl oraz licznych mediów lokalnych, których zasoby internetowe przeszukiwano pod kątem potrzeb bieżącej analizy w okresie od 1 września do 31 grudnia 2016 roku.

\section{METODOLOGIA}

W analizie poszukujemy odpowiedzi na pytanie: czy staż parlamentarny $(S P)$ wpływa na siłę kandydata $(S I)$ w wyborach bezpośrednich do gminnej egzekutywy? Stażem parlamentarnym wykazują się ci kandydaci do stanowisk gminnej egzekutywy od 2002 roku, którzy przez dowolny okres od wyborów parlamentarnych w 2001 roku zajmowali stanowisko posła i/lub senatora, a następnie ubiegali się o funkcję wójta, burmistrza, prezydenta miasta. Stażem parlamentarnym wykazywała się w wyborach w 2006 roku na stanowisko prezydenta m.st. Warszawy Hanna Gronkiewicz-Waltz. W kolejnych startach wyborczych (w 2010 i w 2014 roku) ta osoba nie wykazuje się już $S P$, ponieważ wygrała wybory w 2006 roku i od tego momentu zaczyna działać status inkumbenta. Dlatego zmienna $S P$ jest ,aktywna” $(S P=1)$ jedynie w pierwszym i kolejnych startach wyborczych tej samej osoby, kończących się porażkami w wyścigu o fotel wójta, burmistrza czy prezydenta miasta. Od momentu pierwszego sukcesu wyborczego kolejne starty wyborcze danej osoby nie są już kwalifikowane jako charakteryzujące się stażem parlamentarnym $(S P=0)$.

2 Jeżeli ta sama osoba kandydowała we wszystkich dotychczasowych wyborach, w 2002, 2006, 2010 i w 2014 roku, wówczas tworzy ona cztery obserwacje (generuje cztery starty wyborcze). 
Wyborcza karuzela: staż parlamentarny jako czynnik sukcesu wyborczego kandydatów na wójta...

Natomiast przez siłę kandydata rozumiemy tu odsetek głosów w pierwszej turze zdobywanych przez kandydujących w poszczególnych wyborach bezpośrednich (w latach 2002, 2006, 2010 i 2014), do stanowisk kierowników gminnej egzekutywy. Wartości tej zmiennej pozyskiwano z PKW.

Aby możliwe było zoperacjonalizowanie w powyżej nakreślony sposób zmiennej $S P$ i przypisanie jej wartości $(S P=0$ lub $S P=1)$, dla kandydujących we wszystkich dotychczasowych wyborach bezpośrednich na stanowiska wójtów, burmistrzów i prezydentów miast utworzono bazę wszystkich posłów i senatorów, którzy od czasu wyborów parlamentarnych w 2001 roku, przez dowolny okres (w ramach jednej kadencji lub kilku kadencji), zasiadali w Sejmie i/lub w Senacie RP. Liczebność tak rozumianej grupy określono na 2925 imion i nazwisk osób, które niekiedy wielokrotnie piastują funkcję w ramach pięciu dotychczasowych kadencji parlamentu (2001-2005; 2005-2007; 2007-2011; 2011-2015 i 2015-2019). W dalszej kolejności 2925 nazwisk osób pełniących funkcje posłów i/lub senatorów od 2001 roku zestawiono z nazwiskami zakwalifikowanych startów wyborczych we wszystkich dotychczasowych wyborach bezpośrednich do stanowisk kierowników gminnej egzekutywy $(N=33680)$. Na tej podstawie ustalono zgodność imion i nazwisk z obydwu baz $(N=2925$ i $N=33680)$. Następnie w przypadku wyborów do stanowisk wójtów, burmistrzów, prezydentów miast, weryfikowano, czy mamy do czynienia z tymi samymi osobami, które przed kandydowaniem do stanowisk przedstawicieli gminnej egzekutywy, zasiadały albo w trakcie tych wyborów, zasiadają w parlamencie. Weryfikacja w tym zakresie przebiegała na podstawie analizy biografii parlamentarzystów na podstawie dostępnych w tym zakresie źródeł, którymi były portale instytucji: Sejm.gov.pl, Senat.gov.pl, PKW (pkw.gov.pl), ale także celowe projekty realizowane przez organizacje społeczne: MamPrawoWiedziec.pl, źródła publicystyczne dotyczące poszczególnych parlamentarzystów oraz takie portale, jak Wikipedia.pl. W wyniku tego typu działań stwierdzono liczne przypadki braku w biografiach parlamentarzystów informacji o faktach bezskutecznego ubiegania się o stanowiska wójtów, burmistrzów i prezydentów miast ${ }^{3}$.

W celu weryfikacji wpływu stażu parlamentarnego na uzyskiwany przez kandydatów odsetek głosów wykorzystywano analizę regresji liniowej. Zmienną zależną stanowił odsetek głosów uzyskany w pierwszej turze $(S I)$ wyborów wójta (burmistrza, prezydenta miasta). Zmienne objaśniające to staż parlamentarny $(S P)$ i liczba konkurentów danego kandydata $\mathrm{w}$ danych wyborach $\mathrm{w}$ danej gminie. W stosowanych modelach regresji liniowej zmienna staż przyjmuje wartość 0 - tak oznaczano start kandydata, którego nie charakteryzuje staż

\footnotetext{
Weryfikację zgodności imion i nazwisk w charakteryzowanym tu zakresie ułatwiał dostęp do bazy zakwalifikowanych startów we wszystkich dotychczasowych wyborach bezpośrednich do stanowisk gminnej egzekutywy $(N=33$ 680). Wówczas, nawet jeżeli w biogramach parlamentarzystów nie podawano informacji o fakcie bezowocnego ubiegania się o stanowisko włodarza jakiejś gminy, to i tak możliwa była skuteczna weryfikacja tego stanu rzeczy w wyniku stwierdzenia zgodności nazwisk. W takim przypadku w dalszej kolejności prowadzono identyfikację, czy kandydujący w danych wyborach w danej gminie to ta sama osoba, która miała epizod parlamentarny. W tym zakresie posiłkowano się również doniesieniami lokalnych mediów, bo jak nadmieniono, biogramy parlamentarzystów zamieszczane na stronach instytucji (np. Sejm.gov.pl) lub na stronach organizacji (np. MamPrawoWiedziec.pl) często nie zawierają informacji o bezowocnych próbach ubiegania się o stanowiska wójtów, burmistrzów czy prezydentów miast.
} 
parlamentarny; lub wartość 1 - kiedy mamy do czynienia z kandydatem, który ma za sobą epizod parlamentarny lub w trakcie wyborów do gminnej egzekutywy zasiada w sejmie lub senacie. Z kolei liczba konkurentów operacjonalizowana jest przez pomniejszenie ogólnej liczby kandydatów $\mathrm{w}$ danych wyborach $\mathrm{w}$ danej gminie o jeden $(n-1)$, co przy jednym kandydacie daje 0 konkurentów. Wybór zmiennej $S P$ w roli zmiennej niezależnej jest podyktowany brzmieniem pytania badawczego, $z$ kolei ustalenie liczby kandydatów w roli zmiennej niezależnej wynikało $\mathrm{z}$ faktu, iż jest to zwykle druga zmienna (po statusie inkumbenta) pod względem siły wpływu na wartość szacowanej tu zmiennej zależnej (odsetka głosów w pierwszej turze w przedmiotowych wyborach). Poza tym zmienna „liczba kandydatów” efektywnie zastępuje zmienną „liczba ludności gminy” ze względu na niwelację efektu współliniowości, do czego nawiążemy w dalszej części artykułu.

\section{ZAŁOŻENIA}

Podobną do stażu parlamentarnego $(S P)$ zmienną odnajdziemy w analizie wpływu wybranych czynników na zdobywane głosy w wyborach do rady miejskiej w Chicago w latach 1979-1995, przeprowadzonej przez Timothy’ego Krebsa (Krebs 1998: 924 i 929). Zmienna ta (Political Experience) - jest u Krebsa stopniowana. Jej silniejszy wpływ ma wystąpić wówczas, kiedy - aktualnie albo w przeszłości - dany kandydat zajmuje/zajmował wysokie stanowisko $\mathrm{w}$ administracji rządowej, przy czym nie jest precyzyjnie określony zakres stanowisk, które są tu brane pod uwagę , albo też w przeszłości zajmował stanowisko w radzie miejskiej Chicago (Krebs 1998: 924). Słabszy wpływ tej zmiennej spodziewany jest wówczas, kiedy na przykład dana osoba kandydowała już bezskutecznie do rady miejskiej, była zastępcą radnego lub wolontariuszem partii politycznej (Krebs 1998: 924). Wpływ tej zmiennej w analizowanych przez Krebsa wyborach nie okazał się znaczący, a istotne oddziaływanie zostało odnotowane tylko w dwóch z pięciu rozpatrywanych wyborów (Krebs 1998: 929).

Biorąc pod uwagę powyższe wnioski, w bieżącej analizie również nie spodziewamy się wykazania znaczącego wpływu zmiennej $S P$ na wartość zmiennej zależnej. Jednak w świetle dotychczasowych dowodów empirycznych możemy uściślić nasze przewidywania, na przykład w kierunku oddziaływania zmiennej $S P$ w gminach o różnej liczbie ludności. Wielkość gminy pod względem liczby ludności jest tu zastępowalna przez liczbę konkurentów, gdyż jak już wspomniano, pomaga to uniknąc pułapek związanych ze współliniowością, zważywszy na to, że można wykazać korelację obu zmiennych (korelacja średnia-słaba na poziomie od 0,3 do 0,4). Im większą liczbę ludności ma gmina, tym większej liczby kandydujących w wyborach na przedstawiciela lokalnej egzekutywy możemy się spodziewać. Jednocześnie, jak już wspomniano, liczba konkurentów jest drugim czynnikiem (po statusie osoby ponownie ubiegającej się o wybór), który najefektywniej wyznacza szansę reelekcji w tej grupie stanowisk. O ile bycie inkumbentem najmocniej przybliża do zwycięstwa, o tyle liczba

4 W charakterystyce tej zmiennej czytamy: „Candidates who were current or former officeholders or high-ranking government officials" (Kandydaci aktualnie albo w przeszłości piastujący stanowiska albo urzędnicy rządowi wysokiego szczebla) (Krebs 1998: 924). 
Wyborcza karuzela: staż parlamentarny jako czynnik sukcesu wyborczego kandydatów na wójta...

konkurentów w walce o stanowisko jest jednym z czynników najsilniej „pracujących” na porażkę inkumbentów i obniżającym odsetki uzyskiwanych przez kandydujących głosów w pierwszej turze. Biorąc to pod uwagę, moglibyśmy się spodziewać, że w największych ludnościowo gminach, gdzie zwykle spotykamy relatywnie największą liczbę kandydujących, szanse ponownie ubiegających się o urząd będą najniższe i w takich jednostkach będzie najtrudniej o otrzymanie reelekcji. Tak się jednak nie dzieje. Jak do tej pory, w wyborach bezpośrednich na stanowiska wójtów, burmistrzów i prezydentów miast, właśnie inkumbentom najłatwiej jest uzyskać reelekcję w gminach wiejskich i w miastach na prawach powiatu oraz w miastach wojewódzkich. Najtrudniej zaś utrzymać stanowisko w gminach miejskich, a następnie w miejsko-wiejskich. W ostatnich wyborach (2014 r.) w gminach miejskich, rotacja na stanowiskach kierowników gminnej egzekutywy była najwyższa w porównaniu z pozostałymi typami administracyjnymi gmin, wymieniono tam około 48\% uprzednio rządzących. Taka tendencja była obserwowana we wszystkich dotychczasowych wyborach bezpośrednich na te stanowiska - „nowi” włodarze gmin, nierządzący w poprzedniej kadencji, najczęściej pojawiali się w gminach miejskich i miejsko-wiejskich, a najmniej nowych wybrano w gminach wiejskich, w miastach na prawach powiatu i w największych miastach. Polska nie jest odosobniona pod względem takich prawidłowości. Podobne tendencje odnotowuje się również na przykład w Kanadzie (Kushner, Siegel i Stanwick 1997). Przyczyny takiego stanu rzeczy są dość oczywiste. W gminach mniejszych wyborcy bardziej interesują się sprawami i problemami lokalnymi, co przekłada się na wyższe szanse zwycięstw pretendentów (Callen i Ha 2007: 404; Oliver, Ha i Callen 2012). W dużych ośrodkach wyborcy działają według innej logiki. W Polsce (i nie tylko) frekwencja wyborcza w wyborach lokalnych zwykle maleje wraz ze wzrostem liczby ludności gminy (Swianiewicz 2010: 7-8), co ma stanowić egzemplifikację teorii słabnięcia społeczności (Skarżyńska 2006: 205). Dla wyborcy wielkomiejskiego wybory samorządowe są w pewnej mierze mniej istotne, bo trzeba wybierać spośród wielu kandydatów o potencjalnie wielu programach, a treści na ten temat nie są łatwo dostępne w mediach $\mathrm{w}$ formie skondensowanej, tak jak ma to miejsce na przykład w przypadku wyborów prezydenta kraju ${ }^{5}$. W wyborach lokalnych w gminach o dużej liczbie ludności wyborcy będą bardziej skłonni akceptować sygnały niskokosztowe poznawczo, takie jak status inkumbenta, i będą podejmować decyzje wyborcze, w większym zakresie posługując się uproszczeniami i stereotypami, co wzmacnia ubiegających się o reelekcję.

Bazując na powyższych wnioskach, można przyjąć hipotezę, że kandydaci do stanowisk gminnych włodarzy, charakteryzujący się stażem parlamentarnym $(S P=1)$, będą zdobywać wyższe poparcie w pierwszych turach wyborów bezpośrednich $(S I)$ w większych ośrodkach niż w mniejszych gminach.

Pewną okolicznością mediującą pozostaje w tym przypadku fakt, że w dużych ośrodkach o stanowiska przedstawicieli gminnej egzekutywy mogą ubiegać się byli lub obecni parlamentarzyści, którzy są rozpoznawalni przez wyborców wskutek ich częstego pojawiania się w mediach o zróżnicowanym typie i zasięgu. Weryfikacja tego stanu rzeczy jest jednak utrudniona ze względu na niemożność określenia, w jakich mediach i jak często dana osoba się

Uaktywnienie się w ostatnich wyborach samorządowych tzw. ruchów miejskich niczego w tej mierze nie zmieniło i nie zmieni. 
pojawiała, tym bardziej że analiza obejmuje okres od 2001 roku. Potencjalnym rozwiązaniem tego problemu jest odwołanie się do umocowania w strukturze organizacji partyjnej, jednak zajmowanie wysokiego miejsca $\mathrm{w}$ hierarchii danej partii politycznej nie musi iść $\mathrm{w}$ parze z częstą obecnością w mediach.

Należy również podkreślić brak ograniczeń prawnych w zakresie wyboru gminy, w której były albo obecny parlamentarzysta może ubiegać się o mandat wójta, burmistrza, prezydenta miasta. Jedynym ograniczeniem są potencjalne bariery organizacyjne wynikające z zapisów art. 478 kodeksu wyborczego, a szczególnie w ust. 2 tego artykułu ${ }^{6}$. Aby zgłosić kandydata na wójta (burmistrza, prezydenta miasta), konieczne jest powołanie komitetu wyborczego, który przynajmniej w połowie okręgów wyborczych w gminie zarejestruje listy kandydatów na radnych, a ich liczba w każdym z tych okręgów nie będzie mniejsza od liczby radnych wyłanianych w takim okręgu. Mamy tu zatem do czynienia z ograniczeniami technicznymi, którym może sprostać terenowa struktura partyjna, jeżeli na danym terenie występuje, posiada odpowiednie możliwości organizacyjne oraz jeżeli ocenia, że wystawienie kandydata z doświadczeniem parlamentarnym może przybliżyć szansę na zwycięstwo. Toteż wybór gminy, w której kandyduje były lub obecny parlamentarzysta, jest wynikiem kalkulacji: „gdzie opłaca się najbardziej", ze względu na przykład na rezygnację inkumbenta z ubiegania się o reelekcję w danej gminie (wybory w tzw. trybie open race), czy na podstawie innych uwarunkowań lokalnych. Obecny albo były parlamentarzysta, może wybrać gminę, w której będzie ubiegać się o stanowisko kierownika egzekutywy, w miejscu swojej aktywności życiowej (w którym mieszka i z którym jest zawodowo, rodzinnie i towarzysko powiązany), czy też taką, która jest „stolicą" okręgu wyborczego z wyborów do parlamentu. Wobec braku ograniczeń prawnych może to być każda gmina dająca szansę zwycięstwa i dostępna z punktu widzenia logistycznego. Takie kalkulacje robili zapewne liczni parlamentarzyści sięgający z różnym skutkiem po fotele gminnych włodarzy. Nieudane próby podejmowali na przykład: Dariusz Bachalski, poseł IV kadencji, i senator VI kadencji z okręgu lubuskiego, który w 2006 roku kandydował na prezydenta Gorzowa, zaś w 2010 roku na prezydenta Poznania ${ }^{7}$, Marek Biernacki, poseł wszystkich kolejnych kadencji od 2005 roku, w wyborach samorządowych 2010 roku kandydował na burmistrza Ustki; Józef Cepil, poseł IV i V kadencji z okręgu świętokrzyskiego w 2014 roku kandydował na wójta Nowego Korczyna. Wyborcze sukcesy w samorządach odnieśli na przykład posłowie: Marek Żyliński, poseł IV kadencji z okręgu olsztyńskiego i równocześnie mieszkaniec Olsztyna, który od 2010 roku pełni funkcję burmistrza Zalewa, czy też jego brat Adam Żyliński, poseł III, VI i VII kadencji w 2014 roku wybrany na burmistrza Iławy, a także Robert Biedroń, poseł VII kadencji z okręgu gdyńskiego, który odniósł zwycięstwo w walce o prezydenturę Słupska.

Warto w tym miejscu zadać również pytanie o uwarunkowania decyzji dotyczącej ubiegania się o stanowiska wójtów, burmistrzów, prezydentów miast przez aktualnych i byłych parlamentarzystów. W grę wchodzą tu co najmniej trzy czynniki: aspiracje i kalkulacje jednostkowe, co zależy od bieżącej sytuacji (aktualny versus były parlamentarzysta, a w tym

6 Ustawa z dnia 5 stycznia 2011 roku - Kodeks Wyborczy, Dz.U. z 2011 r. nr 21, poz. 112 z późn. zm.

7 Warto wskazać, że każdy z tych startów odbywał się pod innymi barwami partyjnymi. 
Wyborcza karuzela: staż parlamentarny jako czynnik sukcesu wyborczego kandydatów na wójta...

ostatnim przypadku rolę odgrywa sytuacja zawodowa i ulokowanie polityczne takiej osoby); „wola partii”; ewentualnie, w przypadku aktualnych parlamentarzystów, kalkulacja indywidualna w sytuacji utraty znaczenia w partii i braku jej wsparcia. Bowiem ubieganie się przez byłego, a szczególnie aktualnego parlamentarzystę, o stanowisko prezydenta jednego z miast wojewódzkich, w razie zwycięstwa może być postrzegane przez kandydującego i przez otoczenie raczej jako awans ze stanowiska posła/senatora. Natomiast ubieganie się przez byłego, a w szczególności przez aktualnego parlamentarzystę o stanowisko wójta będzie raczej postrzegane jako degradacja w politycznej hierarchii, toteż zdarza się rzadko. Mamy tu do czynienia z wieloma krzyżującymi się czynnikami, które leżą u podłoża decyzji o kandydowaniu na stanowiska kierowników gminnych egzekutyw przez osoby ze stażem parlamentarnym. Wyczerpująca weryfikacja tych uwarunkowań nie jest możliwa, głównie z powodu zbyt dużego stopnia ich komplikacji i trudności z ustaleniem rzeczywistego stanu rzeczy, na przykład strategii gry partyjnej w danym regionie. Należy jednak pamiętać, że politycy, podobnie jak inni ludzie, w swoich wyborach zawodowych będą raczej dążyć do awansu, ewentualnie do utrzymania stanowiska w kolejnych wyborach, choć na takich decyzjach waży koincydencja uwarunkowań indywidualnych i środowiskowych (Botero 2008: 12 i 32-41).

\section{ANALIZA}

Spośród 33680 zakwalifikowanych startów wyborczych podczas wszystkich dotychczasowych wyborów bezpośrednich do stanowisk gminnej egzekutywy, 327 dotyczyło kandydatów ze stażem parlamentarnym $(S P=1)$. W tabeli 1 przedstawiono starty wyborcze do stanowisk gminnej egzekutywy, które wyróżnia staż parlamentarny oraz starty pozostałych kandydatów $(S P=0)$.

We wszystkich dotychczasowych wyborach bezpośrednich wójtów, burmistrzów i prezydentów miast, pośród startów kandydatów wyróżniających się stażem parlamentarnym odsetek kobiet był w zasadzie taki sam jak wśród pozostałych ubiegających się o te stanowiska (12,8\% w stosunku do 12,9\%). Kandydaci z doświadczeniem parlamentarnym dwa razy częściej niż pozostali kandydaci w takich wyborach startowali z list komitetów partii politycznej lub koalicji partii (64,2\% w stosunku do 30,1\%); częściej też niż pozostali wybierali wybory rozgrywane bez obecności wśród kandydatów urzędującego szefa gminnej administracji (odpowiednio: 16,9\% i 12,6\%). Częściej również kandydowali w dużych ośrodkach (co piąty w miastach wojewódzkich $-22 \%$ ), a niemal połowa takich startów odbyła się w miastach na prawach powiatu $(48,3 \%)$, podczas gdy we wszystkich dotychczasowych wyborach tego typu starty wyborcze pozostałych kandydatów $(N=33353)$ koncentrowały się głównie w gminach wiejskich $(54,9 \%)$ i w miejsko-wiejskich $(27,7 \%)$. Odsetek startów wyborczych kandydatów ze stażem parlamentarnym we wszystkich dotychczasowych wyborach bezpośrednich kierowników gminnej egzekutywy stanowił 0,98\%. Jednocześnie 14,1\% takich startów zakończyło się sukcesem. Wartości dotyczące poszczególnych wyborów od 2002 do 2014 roku zawarto w tabeli 1. 


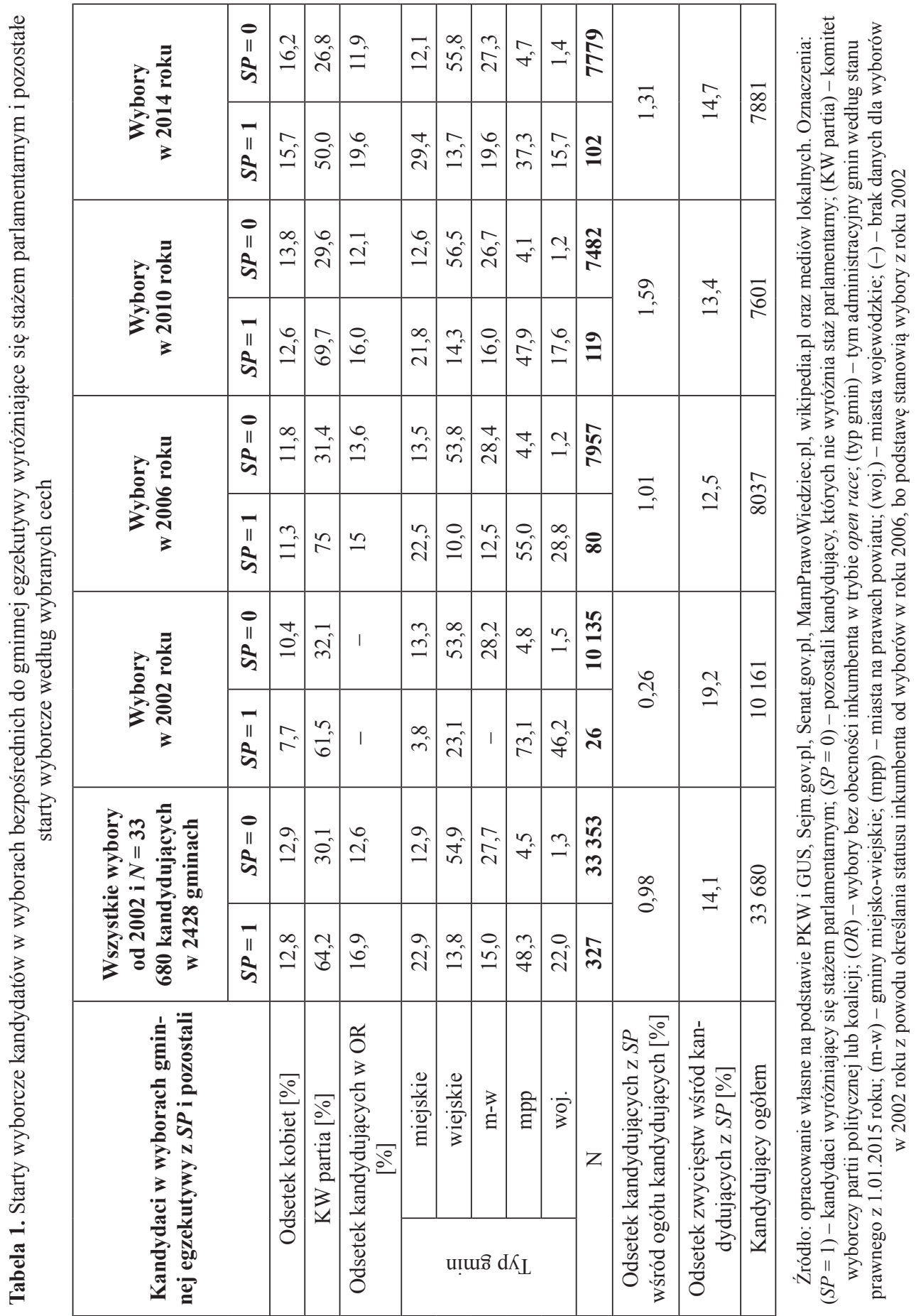


Wyborcza karuzela: staż parlamentarny jako czynnik sukcesu wyborczego kandydatów na wójta...

Poddając analizie starty wyborcze kandydatów ze stażem parlamentarnym w zależności od wielkości gminy, na przykładzie gmin liczących 100 tysięcy i więcej mieszkańców, które były najczęściej wybierane przez kandydujących ze stażem parlamentarnym, ustalono, że spośród 121 dotychczasowych startów w tych gminach (kolumna II, w tabeli 2) dziewięć startów zakończyło się sukcesem, czyli 7,4\% wszystkich takich startów wyborczych w tej wielkości gminach (kolumny III i IV w tabeli 2).

Tabela 2. Starty wyborcze we wszystkich dotychczasowych wyborach bezpośrednich do stanowisk gminnej egzekutywy w 2428 gminach, ze względu na ludnościową wielkość gminy

\begin{tabular}{|l|c|c|c|c|c|c|c|c|c|c|c|}
\hline \multicolumn{1}{|c|}{ I } & II & III & IV & V & VI & VII & VIII & IX & X & XI & XII \\
\hline$<5000$ & 11 & 0 & 0 & 0 & 0 & 0 & 0,0 & 5 & 45,5 & 9,1 & 598 \\
\hline $5000-9999$ & 26 & 6 & 23,1 & 5 & 19,2 & 1 & 16,7 & 10 & 38,5 & 0 & 957 \\
\hline $10000-19999$ & 42 & 4 & 9,5 & 6 & 14,3 & 1 & 25 & 12 & 28,6 & 16,7 & 539 \\
\hline $20000-49999$ & 62 & 16 & 25,8 & 10 & 16,1 & 5 & 31,25 & 36 & 58,1 & 9,7 & 244 \\
\hline $50000-99999$ & 65 & 11 & 16,9 & 12 & 18,5 & 5 & 45,5 & 48 & 73,8 & 12,3 & 53 \\
\hline$>=100$ tys. & 121 & 9 & 7,4 & 18 & 14,9 & 2 & 22,2 & 99 & 81,8 & 16,5 & 37 \\
\hline Ogółem & 327 & 46 & 14,1 & 51 & 15,6 & 14 & 30,4 & 210 & 64,2 & 12,8 & 2428 \\
\hline
\end{tabular}

Źródło: opracowanie własne na podstawie: PKW, GUS, Sejm.gov.pl, Senat.gov.pl, MamPrawoWiedziec.pl, Wikipedia.pl oraz mediów lokalnych. Oznaczenia kolumn: (I) - liczba ludności gmin szacowana dynamicznie na 31 grudnia 2002, 2006, 2010 i 2014 roku; (II) $-N$ kandydujących z $S P=1$; (III) $-N$ zwycięstw spośród $N$ kandydujących z $S P=1$; (IV) - procent zwycięstw spośród $N$ kandydujących z $S P=1 ;(\mathrm{V})-N$ startów w wyborach bez obecności inkumbenta (open race) z $S P=1$; (VI) - procent startów w wyborach bez obecności inkumbenta; (VII) - N zwycięstw w wyborach bez obecności inkumbenta; (VIII) - procent zwycięstw w wyborach bez obecności inkumbenta do $N$ zwycięstw (w kolumnie II); (IX) - $N$ kandydujących pod szyldem komitetów partii lub koalicji; (X) - procent kandydujących pod szyldem partii lub koalicji; (XI) - procent kobiet wśród kandydujących; (XII) $-N$ gmin według liczby ludności z 31.12.2014 roku według kategorii w kolumnie I

Wśród 121 startów wyróżniających się stażem parlamentarnym, w gminach liczących 100 tysięcy i więcej ludności w danym roku wyborczym, 18 odbywało się w wyborach bez obecności inkumbenta, co oznacza 14,9\% startów wyborczych w wyścigu typu open race (kolumny V i VI tabeli 2). Wreszcie, dwa starty w wyborach, w których nie kandydował inkumbent, zakończyły się sukcesem w stosunku do ogółu odnotowanych zwycięstw w tym segmencie gmin (9), co oznacza, że 22,2\% zwycięstw w tym segmencie gmin pochodzi ze startów w wyborach open race (kolumny VII i VIII w tabeli 2). W tym segmencie gmin spośród 121 startów wyborczych $99(81,8 \%)$ realizowano pod szyldem komitetów wyborczych partii politycznej lub koalicji (kolumny IX i X tabeli 2), a w 16,5\% spośród nich kandydowały kobiety (kolumna XI tabeli 2). W kolumnie XII w tabeli 2 wykazano liczebności gmin według danego przedziału ludności zgodnie z kwalifikacją w tym względzie z roku 2014. Należy przy tym pamiętać, że status inkumbenta można 
określić, poczynając od wyborów w 2006 roku, ponieważ podstawą w tym zakresie są pierwsze wybory bezpośrednie kierowników gminnej egzekutywy z roku 2002. W wyborach w 2002 roku nie określano statusu inkumbenta z okresu wybierania pośredniego włodarzy gminnych. Natomiast w kolumnie I tabeli 2 liczebność ludności gmin określana jest dynamicznie, co oznacza podanie liczby ludności według stanu na każdy rok wyborów (2002, 2006, 2010 i 2014).

Z danych w tabeli 2 odczytujemy, że osobom, które charakteryzuje staż parlamentarny, nie opłaca się kandydować w największych ludnościowo gminach, bo szanse na wygraną należą do najniższych, mimo że próby zdarzają się tam najczęściej. Podobnie jest w gminach poniżej 5 tysięcy mieszkańców, gdzie żadne z 11 podejść wyborczych nie zakończyło się sukcesem. Najwięcej sukcesów w stosunku do startów wyborczych odnotowują gminy liczące od 20 tysięcy do 50 tysięcy mieszkańców (25,8\%), a następnie gminy z liczbą ludności od 5 tysięcy do 10 tysięcy $(23,1 \%)$. Można zauważyć, że kandydaci posiadający staż parlamentarny dostrzegają gminy, w których nie kandyduje urzędujący wójt (burmistrz, prezydent miasta), i tam zgłaszają swoją kandydaturę, z czego co piąty w gminach od 5 tysięcy do 10 tysięcy ludności i w gminach od 50 tysięcy do 100 tysięcy ludności (odpowiednio 19,2\% i 18,5\%). Zabiegi takie opłacają się szczególnie w tym ostatnim typie gmin, gdzie 45,5\% wszystkich zwycięstw zrealizowano właśnie w wyborach typu open race.

W dalszej kolejności przeprowadzono analizę regresji liniowej na bazie dwóch czynników z efektem interakcji. Czynnikiem pierwszym jest liczba konkurentów w danych wyborach (2002, 2006, 2010 i 2014), jednocześnie zmienna ta pełni funkcję moderatora w interakcji. Czynnikiem drugim jest zmienna staż parlamentarny $(S P=0$ lub 1). Zmienną zależną jest odsetek głosów w pierwszej turze danych wyborów $(S I)$. Efekt interakcji ma występować, jeżeli wpływ zmiennej niezależnej $(S P)$ na zmienną zależną $(S I)$ podlega zmianom ze względu na wartości innej zmiennej niezależnej (liczba konkurentów - moderator interakcji). Predykcję w tym zakresie przedstawiono w tabeli 3. Wyniki efektu interakcji przedstawione w tabeli 3 należy interpretować ostrożnie. Wartość stałej w modelu wychwytującym interakcję, dla niestandaryzowanej bety wynosi 196,434, przy $p<0,000$. Dzieje się tak wskutek przekroczenia wartości krytycznej VIF, którą możemy określić na 10 (Mycielski 2010: 153). Nadmiernego wpływu współliniowości nie sposób tu wyeliminować.

Podobnie usunięcie spośród startów wyborczych tych reprezentowanych przez inkumbentów czy też usunięcie obserwacji dla Warszawy (jako obserwacji odstających), nie poprawia parametrów modelu. Charakteryzowany efekt można lepiej dostrzec i zinterpretować, posługując się w tym celu prezentacją graficzną pokazaną na rysunkach 1 i 2 . Na wykresach tych starty wyborcze kandydatów charakteryzujących się stażem parlamentarnym zwizualizowano za pomocą punktów w kolorze czarnym. Na każdy z wykresów naniesiono liniowe estymatory rozkładu wartości dla zmiennej SI, gdzie estymator w postaci linii ciągłej oznacza przeciętne wartości zmiennej $S I$ w grupie startów wyborczych niecharakteryzujących się stażem parlamentarnym $(S P=0)$, a linia przerywana to trend przeciętnej wartości zmiennej zależnej $(S I)$ w grupie startów wyborczych charakteryzujących się stażem parlamentarnym $(S P=1)$. 
Wyborcza karuzela: staż parlamentarny jako czynnik sukcesu wyborczego kandydatów na wójta...

Tabela 3. Ocena wpływu efektu interakcji zmiennych: liczba konkurentów i $S P$ na zmienną $S I$

\begin{tabular}{|c|c|c|c|c|}
\hline Zmienna zależna: $S I$ & B & $S E$ & Beta & $p$ \\
\hline Liczba konkurentów & $-4,118$ & 0,059 & $-0,8$ & 0,000 \\
\hline$S P($ tak $=1 ;$ nie $=0)$ & $-3,213$ & 0,117 & $-0,317$ & 0,000 \\
\hline Stała & 55,547 & 1,117 & & 0,000 \\
\hline$N$ & \multicolumn{4}{|c|}{33680} \\
\hline$R$-kwadrat skorygowany & \multicolumn{4}{|c|}{$52 \%$} \\
\hline Liczba konkurentów & $-10,601$ & 0,134 & $-2,058$ & 0,000 \\
\hline$S P(\operatorname{tak}=1 ;$ nie $=0)$ & 4,13 & 0,177 & 0,407 & 0,000 \\
\hline Liczba konkurentów $\times S P(\operatorname{tak}=1 ;$ nie $=0)$ & $-0,33$ & 0,006 & $-1,958$ & 0,000 \\
\hline Stała & 196,434 & 2,847 & & 0,000 \\
\hline$N$ & \multicolumn{4}{|c|}{33680} \\
\hline$R$-kwadrat skorygowany & \multicolumn{4}{|c|}{$58 \%$} \\
\hline
\end{tabular}

Źródło: obliczenia własne, na podst. PKW, Sejm.gov.pl, Senat.gov.pl, MamPrawoWiedziec.pl, Wikipedia.pl oraz mediów lokalnych

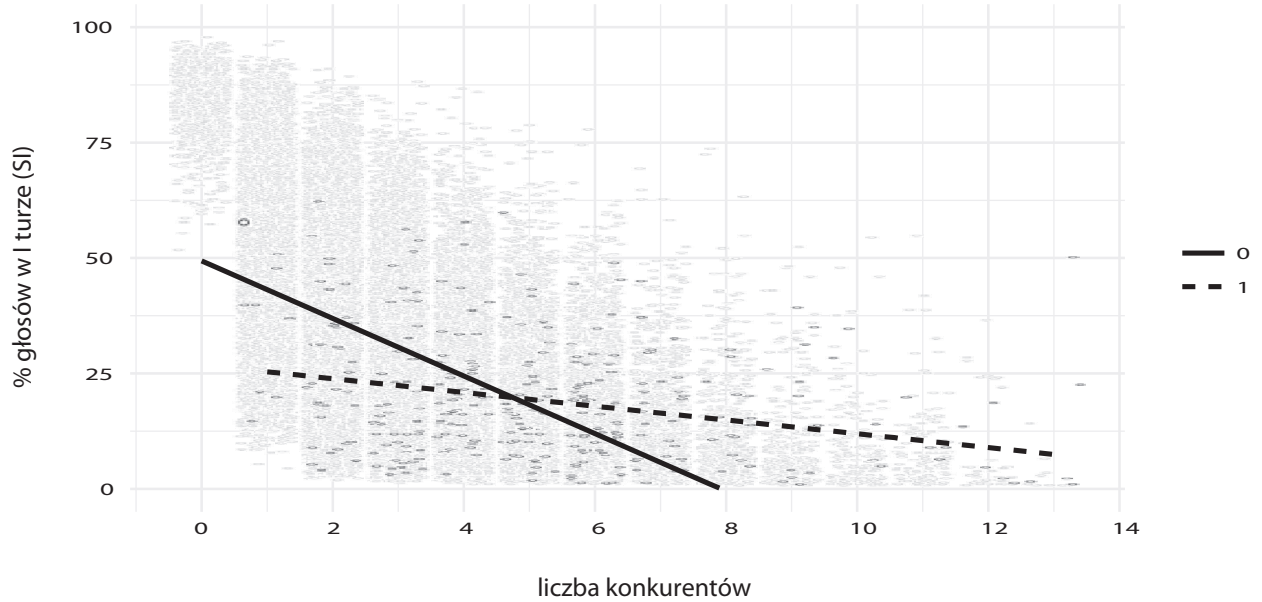

Rys. 1. Przeciętne wartości $S I$ dla $S P=0$ i $S P=1 \mathrm{z}$ uwzględnieniem liczby konkurentów

Źródło: opracowanie własne na podstawie PKW, Sejm.gov.pl, Senat.gov.pl, MamPrawoWiedziec.pl, Wikipedia.pl oraz mediów lokalnych

Na rysunku 1 dla przedstawienia przeciętnych wartości zmiennej zależnej $(S I)$ zarówno dla startów wyborczych charakteryzujących się stażem parlamentarnym $(S P=1)$, jak i dla pozostałych startów wyborczych $(S P=0)$, na osi OX użyto moderatora efektu 
interakcji z tabeli 3, czyli liczby konkurentów. Na rysunku 2 moderator został zastąpiony przez liczbę ludności gmin w postaci logarytmu naturalnego. Jak wcześniej wspominano, zastąpienie liczby ludności przez liczbę konkurentów w danych wyborach ogranicza efekt współliniowości, ale jak wynika z danych w tabeli 3 , nie jest to rozwiązanie w pełni satysfakcjonujące. Istotne na wykresach (rys. 1 i 2 ) jest to, że dostrzegamy potencjalny efekt interakcji (przecięcia linii). W miarę wzrostu liczby ludności gminy (wzrasta też liczba kandydujących), przeciętne wartości zmiennej zależnej $(S I)$ ulegają obniżeniu zarówno w grupie startów ze stażem parlamentarnym, jak i wśród pozostałych. Tyle że niwelacja przeciętnych wartości zmiennej zależnej wraz ze wzrostem populacji jest większa w przypadku kandydatów niewyróżniających się stażem parlamentarnym $(S P=0$, linia ciągła na wykresach), niż wśród tych, których wyróżnia staż parlamentarny ( $S P=1$, linia przerywana na obydwu wykresach).

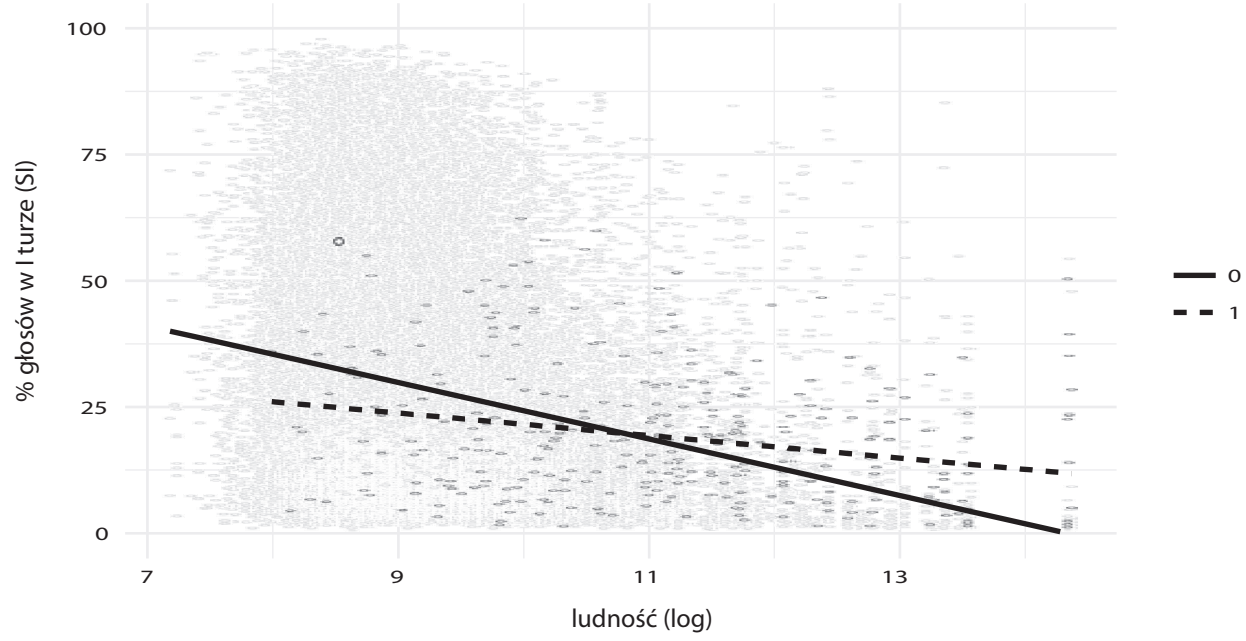

Rys. 2. Przeciętne wartości $S I$ dla $S P=0$ i $S P=1 \mathrm{z}$ uwzględnieniem ludności gmin (log) Źródło: opracowanie własne na podstawie PKW, Sejm.gov.pl, Senat.gov.pl, MamPrawoWiedziec.pl, Wikipedia.pl oraz mediów lokalnych

Aby dokładniej wychwycić oddziaływanie zmiennej staż parlamentarny, utworzono modele regresji liniowej dwuczynnikowej w ramach grup gmin o określonej liczbie ludności według stanu z 31 grudnia 2014 roku, a efekty tych predykcji zamieszczono w tabeli 4.

W tabeli 4 przedstawiono sześć modeli regresji liniowej z dwoma czynnikami wprowadzanymi jednocześnie. Modele przedstawiają predykcję dla startów wyborczych w różnych grupach gmin pochodzących z jednej populacji $(N=33680)$. W zakresie startów wyborczych wyłącznie w miastach wojewódzkich staż parlamentarny nie wpływa istotnie na poparcie wyborcze w pierwszej turze, wynik bety niestandaryzowanej w tym przypadku ma wartość 
Wyborcza karuzela: staż parlamentarny jako czynnik sukcesu wyborczego kandydatów na wójta...

dodatnią. W miastach na prawach powiatu (włączając miasta wojewódzkie), również nie stwierdzamy istotności wpływu interesującej nas zmiennej. Podobnie dzieje się w przypadku startów we wszystkich gminach o ludności w roku wyborów $\leq 100$ tysięcy, przy tym jednak znak niestandaryzowanej bety przyjmuje już wartość ujemną. Wreszcie, biorąc pod uwagę starty wyborcze jedynie w gminach $\leq 50$ tysięcy ludności w roku wyborów, wskaźnik $p$ zbliża się do poziomu istotnego ( $p=0,081)$, a znak w becie wskazuje wartość ujemną. Rozpatrując starty wyborcze wyłącznie $w$ gminach $\mathrm{z}$ ludnością $\leq 20$ tysięcy oraz $\leq 10$ tysięcy, uzyskujemy istotny wpływ zmiennej staż parlamentarny. W obydwu przypadkach wykazywanie tej cechy powodowało utratę głosów w pierwszych turach wyborów bezpośrednich kierowników gminnej egzekutywy (tabela 4).

Tabela 4. Modele regresji dla siły kandydata $(S I)$ budowanej przez staż parlamentarny i liczbę kontrkandydatów

\begin{tabular}{|c|c|c|c|c|c|c|c|c|}
\hline \multirow[t]{2}{*}{ Zmienna zależna: $S I$} & \multicolumn{4}{|c|}{$\begin{array}{l}\text { Ludność } \leq 20 \text { tys. } \\
\text { w roku wyborów }\end{array}$} & \multicolumn{4}{|c|}{$\begin{array}{l}\text { Ludność } \leq 10 \text { tys. } \\
\text { w roku wyborów }\end{array}$} \\
\hline & $B$ & $S E$ & beta & $p$ & $B$ & $S E$ & beta & $p$ \\
\hline liczba kontrkandydatów & $-7,399$ & 0,066 & $-0,566$ & 0 & $-8,262$ & 0,085 & $-0,573$ & 0 \\
\hline$S P(1=$ tak; $0=$ nie $)$ & $-7,238$ & 2,103 & $-0,017$ & 0,001 & $-9,493$ & 3,102 & $-0,018$ & 0,002 \\
\hline stała & 52,646 & 0,226 & & 0 & 54,845 & 0,27 & & 0 \\
\hline$N$ & \multicolumn{4}{|c|}{26957} & \multicolumn{4}{|c|}{19307} \\
\hline$R$-kwadrat skorygowany & \multicolumn{4}{|c|}{$32 \%$} & \multicolumn{4}{|c|}{$33 \%$} \\
\hline \multirow[t]{2}{*}{ Zmienna zależna: $S I$} & \multicolumn{4}{|c|}{$\begin{array}{l}\text { ludność } \leq 100 \text { tys. } \\
\text { w roku wyborów }\end{array}$} & \multicolumn{4}{|c|}{$\begin{array}{l}\text { ludność } \leq 50 \text { tys. } \\
\text { w roku wyborów }\end{array}$} \\
\hline & $B$ & $S E$ & beta & $p$ & $B$ & $S E$ & beta & $p$ \\
\hline liczba kontrkandydatów & $-6,601$ & 0,054 & $-0,56$ & 0 & $-6,923$ & 0,058 & $-0,562$ & 0 \\
\hline$S P(1=$ tak; $0=$ nie $)$ & $-0,825$ & 1,286 & $-0,003$ & 0,522 & $-2,715$ & 1,557 & $-0,008$ & 0,081 \\
\hline Stała & 50,375 & 0,204 & & 0 & 51,256 & 0,21 & & 0 \\
\hline$N$ & \multicolumn{4}{|c|}{32645} & \multicolumn{4}{|c|}{31372} \\
\hline$R$-kwadrat skorygowany & \multicolumn{4}{|c|}{$31 \%$} & \multicolumn{4}{|c|}{$32 \%$} \\
\hline \multirow[t]{2}{*}{ Zmienna zależna: $S I$} & \multicolumn{4}{|c|}{ miasta wojewódzkie } & \multicolumn{4}{|c|}{ MPP wg 1.01.2015 } \\
\hline & $B$ & $S E$ & beta & $p$ & $B$ & $S E$ & beta & $p$ \\
\hline liczba kontrkandydatów & $-1,726$ & 0,259 & $-0,281$ & 0 & $-2,081$ & 0,161 & $-0,302$ & 0 \\
\hline$S P(1=$ tak; $0=$ nie $)$ & 1,777 & 2,009 & 0,037 & 0,377 & 1,21 & 1,313 & 0,022 & 0,357 \\
\hline Stała & 25,935 & 2,098 & & 0 & 28,315 & 1,088 & & 0 \\
\hline$N$ & \multicolumn{4}{|c|}{521} & \multicolumn{4}{|c|}{1665} \\
\hline$R$-kwadrat skorygowany & \multicolumn{4}{|c|}{$8 \%$} & \multicolumn{4}{|c|}{$9 \%$} \\
\hline
\end{tabular}

Źródło: opracowanie własne na podst. PKW, Sejm.gov.pl, Senat.gov.pl, MamPrawoWiedziec.pl, Wikipedia.pl oraz mediów lokalnych. Oznaczenia: (MPP) - miasta na prawach powiatu 


\section{WNIOSKI}

Przeprowadzona analiza miała na celu oszacowanie wpływu stażu parlamentarnego na poziom poparcia $\mathrm{w}$ pierwszych turach wyborów bezpośrednich na wójtów, burmistrzów i prezydentów miast. Wykorzystując bazę zakwalifikowanych startów wyborczych $(N=33680)$ w elekcjach od 2002 do 2014 roku, stwierdzono 327 startów kandydatów mających staż parlamentarny. Taki poziom zainteresowania byłych i obecnych parlamentarzystów stanowiskami kierowników gminnych egzekutyw, w perspektywie czterech tur wyborów bezpośrednich do tych stanowisk, można ocenić jako niewielki. Stwierdzono, że wyróżnianie się stażem parlamentarnym podczas kandydowania w mniejszych gminach, szczególnie w tych poniżej 20 tysięcy mieszkańców, nie wpływa korzystnie na poziom głosów uzyskiwanych w pierwszych turach tych wyborów. Jednocześnie staż parlamentarny w przypadku kandydowania w gminach z dużą liczbą ludności nie zwiększa istotnie poparcia wyborczego przy ubieganiu się o stanowiska lokalnych włodarzy. Choć z drugiej strony odsetki dotychczasowych zwycięstw w gminach o różnej wielkości (tabela 2) wskazują, że najwyższe szanse na sukces istnieją w gminach liczących od 5 tysięcy do 50 tysięcy mieszkańców. Największe ośrodki (powyżej 100 tysięcy ludności), mimo że cieszą się najwyższym zainteresowaniem byłych i obecnych parlamentarzystów, to pozostają najtrudniejsze do zdobycia.

Wydaje się, że stanowiska lokalnych włodarzy, szczególnie w większych ośrodkach, stają się coraz bardziej pożądane przez polityków szczebla krajowego i ogólnopolskie partie polityczne. Główne przyczyny takiego stanu rzeczy to sukcesy samorządu terytorialnego oraz wprowadzone od 2002 roku zmiany kompetencyjno-ustrojowego umocowania organu wykonawczego gminy, co w praktyce daje znaczne możliwości, bo kierownik gminnej egzekutywy to monokratyczny organ wyposażony w daleko idącą władzę nad wszelkimi obszarami lokalnej rzeczywistości. Jednak w tym ,pochodzie na samorząd” są pewne strukturalne przeszkody, z których wydaje się, że parlamentarzyści zdają sobie sprawę, a które wykazano w analizie i być może z tego powodu ów „pochód” ma raczej symboliczny charakter, ewentualnie z przeświadczeniem, że „być może się uda”. Szanse na to są większe, jeżeli inkumbent nie kandyduje, i dodatkowo rosną w segmencie tych gmin, w których rotacja rządzących jest najwyższa, czyli raczej w gminach miejskich i miejsko-wiejskich od 20 tysięcy do 100 tysięcy ludności. Jeżeli były lub obecny parlamentarzysta zdecyduje się, aby tym razem działać dla dobra jakiejś społeczności gminnej, to raczej tam powinien skierować swe kroki w nadchodzących wyborach i wybierać starcia, w których nie spotka się z osobą ubiegającą się o reelekcję, co nie powinno być trudne w sytuacji zapowiadanego ograniczenia dopuszczalnej liczby kadencji dla piastujących te stanowiska.

Wypracowane w artykule wnioski są zbliżone do obserwacji odnotowywanych w innych miejscach świata w zakresie wyborów lokalnych, podobnie jak wnioski dotyczące różnych aspektów tych wyborów (np. Bartnicki 2017, 2018). Mimo to wiele pozostaje jeszcze do odkrycia, jak choćby oszacowanie prawdopodobieństwa kandydowania w wyborach kolejnych (Castro i Martins 2011); określenie wielkości „efektu inkumbenta” za pomocą metod quasi-eksperymentalnych (np. Trounstine 2011); określenie wpływu miejsca na karcie wyborczej na wielkość poparcia w pierwszej turze i/lub szanse zwycięstwa wyborczego (np. Chen, Simonovits, Krosnick i Pasek 2014) oraz udzielenie odpowiedzi na inne pytania 
Wyborcza karuzela: staż parlamentarny jako czynnik sukcesu wyborczego kandydatów na wójta...

badawcze w tym nurcie, na które odpowiedzi już padły w literaturze światowej. W związku z tym żywimy nadzieję, że skutki projektu „Uwarunkowania reelekcji egzekutywy gminnej po 2002 roku w Polsce” pozwolą na stopniowe „odczarowywanie” tych wyborów i szeroką konfrontację wyników. To z kolei powinno przybliżyć nam preferencje polskich wyborców i ułatwiać diagnozę ich zachowania w tego typu wyborach.

\section{BIBLIOGRAFIA}

Bartnicki, Sławomir. 2017. Wybrane determinanty poparcia kandydatów podczas wyborów gminnego organu wykonawczego, „Studia Wyborcze” 23: 107-129.

Bartnicki, Sławomir. 2018. Uwarunkowania dominacji ubiegajacych się o reelekcje do organu wykonawczego gmin w wyborach $w 2014$ roku, w gminach nie będacych miastami na prawach powiatu, „Samorząd Terytorialny” [w druku].

Brender, Adi i Allan Drazen. 2008. How do budget deficits and economic growth affect reelection prospects? Evidence from a large panel of countries, „American Economic Review" 98: 2203-2220.

Botero, Felipe. 2008. Ambitious Career-Seekers: An Analysis of Career Decisions and Duration in Latin America, http://arizona.openrepository.com/arizona/bitstream/10150/195024/1/ azu_etd_2658_sip1_m.pdf [1.09.2016].

Castro, Vitor i Rodrigo Martins. 2011. Mayors Reelection Choice and the Economy: Evidence from Portugal, NIPE, Working Paper 06.

Chen Eric, Simonovits Gabor, Krosnick Jon A. i Josh Pasek. 2014. The impact of candidate name order on election outcomes in North Dakota, „Electoral Studies” 35: 115-122.

Duraisamy P., Bertrand Lemennicier i Michele Khouri. 2014. Incumbency effect in the Indian Parliamentary Elections, 2004 and 2009: a regression discontinuity approach, „Journal of Quantitative Economics" 12: 12-30.

Drazen, Allan. 2008. Political Budget Cycles, w: Durlauf S.N., Blume L.E. (red.), The new palgrave dictionary of economics, second edition, Palgrave Macmillan, http://www.dictionaryofeconomics.com/article?id=pde2008_P000346 [26.07.2016].

Freier, Ronny. 2015. The mayor's advantage: Casual evidence on incumbency effects in German mayoral elections, „European Journal of Political Economy” 40: 16-30.

Gelman, Andrew i Gary King. 1990. Estimating incumbency advantage without bias, „American Journal of Political Science" 34: 1142-1164.

Heinmueller, Jens i Holger Lutz Kern. 2008. Incumbency as a source of spill over effects in mixed electoral systems: Evidence from a regression-discontinuity design, „Electoral Studies" 27: 213-227.

Kowalik, Janina. 2006. Czynniki wptywajace na potencjalne zachowania wyborców w wyborach samorzadowych 2006 w kontekście zmiany pozycji organu wykonawczego w gminie, „Ateneum Polskie Studia Politologiczne” 14-15: 181-198.

Kuković, Simona i Miro Haček. 2013. The Re-Election of Mayros in the Slovenian Local Self-Government, „Lex Localis - Journal of Local Self-Government” 11: 87-99. 
Kushner, Joseph, David Siegel i Hannah Stanwick. 1997. Ontario Municipal Elections: Voting Trends and Determinants of Electoral Success in a Canadian Province, „Canadian Journal of Political Science" 30: 539-553.

Krebs, Timothy. 1998. The Determinants of Candidates Vote Share and Advantages of Incumbency in City Council Elections, „American Journal of Political Science” 42: 921-935.

Lee, David. 2001. The Electoral Advantage to Incumbency and Voters' Valuation of Politicians'Experience: A Regression Discontinuity Analysis of Elections to the U.S. House, National Bureau of Economic Research. Working Paper 8441.

Lee, David. 2008. Randomized Experiments from Non-random Selection in U.S. House Elections, ,Journal of Econometrics” 142: 675-697.

Lemennicier, Bertrand i Honorine Katir-Lescieux. 2010. Testing the accuracy of the Downs spatial voter model on forecasting the winners of the French parliamentary elections in May-June 2007, „International Journal of Forecasting” 26: 32-41.

Macdonald, Bobbie. 2014. Estimating Incumbency Advantages in African Politics: Regression discontinuity evidence from Zambian parliamentary and local government elections, Working Paper Series 2014, London School of Economics and Political Science.

Mycielski, Jerzy. 2010. Ekonometria, Wydział Nauk Ekonomicznych, Uniwersytet Warszawski.

Oliver, Eric i Shang Ha. 2007. Vote Choice in Suburban Elections, „American Political Science Review" 3: 393-408.

Oliver, Eric, Shang Ha i Zachary Callen. 2012. Local Elections and the Politics of SmallScale Democracy, Princeton.

Peltzman, Sam. 1992. Voters as fiscal conservatives, „Quarterly Journal of Economics” 107: 327-361.

Titiunik, Rocio. 2011. Incumbency Advantage in Brazil: Evidence from Municipal Mayor Elections (under revision), University of Michigan.

Sarpietro, Silvia. 2014. Determinants of Reelection in Portuguese Municipal Elections, Work Project presented as part of the requirements for the Award of a Masters Degree in Economics from the NOVA - School of Business and Economics.

Stonecash, Jeffrey. 2008. Reassessing the Incumbency Effect, Cambridge University Press.

Skarżyńska, Krystyna. 2005. Człowiek a polityka. Zarys psychologii politycznej, Wydawnictwo Naukowe Scholar, Warszawa.

Swianiewicz, Paweł. 2010. Czy rozmiar ma znaczenie? Zróżnicowanie opinii mieszkańców o funkcjonowaniu samorządów lokalnych w zależności od wielkości gminy, „Samorząd Terytorialny" 4: 5-16.

Tarkowski, Jacek. 1994. Patroni i klienci, Instytut Studiów Politycznych PAN, Warszawa.

Taylor, Zack i McEleney, Sandra. 2015. The advantages of incumbency and the determinants of municipal candidate vote share: The 2014 City of Toronto Election, https://www.assocsrv.ca/cpsa-acsp/2015event/Taylor-McEleney.pdf [1.06.2016].

Trounstine, Joustine. 2011. Evidence of a Local Incumbency Advantage, „Legislative Studies Quarterly" 36: 255-280.

Uppal, Yogesh. 2009. The disadvantaged incumbents: estimating incumbency effects in Indian state legislatures, „Public Choice” 138: 9-27. 
Wyborcza karuzela: staż parlamentarny jako czynnik sukcesu wyborczego kandydatów na wójta...

Własiuk, Tomasz. 2011. Przejawy klientelizmu w życiu politycznym współczesnej Polski, Rozprawa doktorska napisana pod kierunkiem Jacka Raciborskiego, Uniwersytet Warszawski, Wydział Filozofii i Socjologii, Instytut Socjologii [maszynopis].

Veiga, Linda Gonçalves, Francisco Jose Veiga. 2007. Political business cycles at the municipal level, „Public Choice” 131: 45-64.

\section{ELECTION CAROUSEL: PARLIAMENTARY EXPERIENCE AS A SUCCESS FACTOR WHILE RUNNING FOR COMMUNE HEAD OR MAYOR}

The subject of this paper is the analysis of what influence has the seniority in the parliament on gaining support, expressed in percentage, in direct elections for these positions: commune head and mayors. Ever since 2002 and up to 2014, among all people attempting to be elected as commune heads and mayors $(N=33680)$ were 327 people who previously (prior to 2001) sat in the Polish Parliament. The analysis results, show that experienced parliamentarians loose support in smaller communities and in large towns and cities parliamentary experience is not a significant variable to enhance odds of election to executive positions.

Keywords: commune head, mayor, reelection factors, parliamentarians in local government 